\title{
PRODUCTION AND PERSISTENCE OF SHORT-TERM RYEGRASSES IN THE NORTHERN NORTH ISLAND
}

\author{
N.S. Percival', G.J. Goold ${ }^{2}$, G.J. Piggot ${ }^{3}$ and L.J. Cranshaw ${ }^{1}$ \\ MAFTech, ${ }^{1}$ Rotorua, ${ }^{2}$ Ruakura, ${ }^{3}$ Whangarei
}

\begin{abstract}
A range of short-term ryegrasses. including the Grasslands cultivars Moata, Paroa. Tama and Manawa, and Progrow and Corvette, were evaluated at 4 sites in Northland, Waikato and Bay of Plenty. At three of the sites comparisons were also made with Ellett or 'Grasslands Nui perennial ryegrasses.

Tama and Progrow had strong winter growth but later were relatively poor. Moata and Paroa had stonger spring growth than Tama or Progrow. The persistence beyond one year of Moata and Paroa in grazed pastures was poor. Corvette, an Italian ryegrass ecotype from near Tauranga, had consistently higher yields than Manawa Moata or Paroa This sometimes increased total pasture yields. Corvette also had ability to persist at least 4 years after sowing. None of the short-term ryegrasses gave summer or autumn productivity as high as Nui or Ellett ryegrasses. A mixture of Ellett and Corvette showed seasonal growth characteristics of both cultivars. implying a production advantage over either sown alone.

This paper advocates re-evaluating the role of short-term ryegrasses in the Auckland Province, consequent on the apparent ability of Corvette to co-exist with perennial
\end{abstract} ryegrasses.

Keywords: Italian ryegrass, Moata, Paroa, Te Puna, Corvette, Tams, Progrow, Manawa, Nui, Ellett, persistence

\section{INTRODUCTION}

For almost 30 years the only short-term ryegrass cultivars available in New Zealand were 'Grasslands Paroa' and 'Grasslands Manawa'. 'Grasslands Tama', a cultivar of Westerwolds ryegrass, was released in 1968 and 'Grasslands Moata' in 1980. All these are cultivars of Lolium multiflorum Lam., except Manawa which is a hybrid between L. multiflorum and perennial ryegrass (Lolium perenne L.).

With the exception of Manawa all these cultivars have a life span in pasture of 1 . 2 years. In developing land for pastoral agriculture, it was standard practice to sow a proportion of the seed mix as short-term ryegrasses. Their role was to provide a bulk of forage in the 1-2 years after sowing and to prevent weed ingression. Through the 1970s farmers tended to leave out the short-term ryegrass and sow only perennial ryegrasses.

We have observed that many old pastures in the northern part of the North Island contain a significant content of Italian type ryegrasses. These appear to have persisted without introduction of new seed and co-exist with perennial ryegrasses.

In the 1970 s and 1980 s collections were made of 3 short-term ryegrass populations from the Auckland province. These were Corvette ryegrass (previously known as Te Puna) from near Tauranga, Te Rahu ryegrass from near Edgecumbe and Concord ryegrass from Orini in Waikato. Each of these is predominantly Italian ryegrass, as characterised both by seed protein banding patterns and a high percentage of fluorescent seedlings (Forde et al. 1988). However, each also shows some perennial ryegrass traits (Forde et al. 1988). The common characteristics of these ecotypes are their ability to co-exist with perennial ryegrasses over a number of years and their strong spring growth.

The identification and potential availability of new cultivars derived from local 
ecotypes required a reassessment of the role of short-term ryegrasses in perennial pasture mixtures. This paper reports on a number of evaluations involving Corvette and other short-term ryegrasses in Northland, Waikato and Bay of Plenty.

\section{METHODS}

\section{Evaluations under mowing}

Seven trials, each over 9-12 months, evaluated a range of short-term ryegrasses sown into cultivated ground as pure species. The trials were sown in autumn and contained 4 replicates. The plots were divided into 2- and 4-, or 3- and 6- week cutting interval subtreatments. The basal sowing rate of Moata was $20 \mathrm{~kg} /$ ha with all cultivars sown at the same number of viable seeds per ha. The plots were cut with rotary mowers to a height of $3-4 \mathrm{~cm}$. N, P, K fertilisers were applied regularly to substitute for nutrients removed in the clippings. Data from individual cuts were pooled into whole seasons.

Trials A-C each compared Manawa, Moata and Corvette and were sown annually from 1983-85 at the Rukuhia Research Station near Hamilton. Trial D, near Edgecumbe, was sown only in 1983, with Paroa, Moata, Tama and Corvette. Trials EG, sown from 1984-86, were also at Rukuhia and compared Paroa, Moata, Tama and Progrow.

\section{Evaluations under grazing}

Katikati site Plots of Corvette, Manawa and Paroa were compared with Nui perennial ryegrass from May 1979 . August 1983 in $90 \mathrm{~m}^{2}$ plots, on a yellow-brown loam soil. The seed was broadcast into cultivated ground at a sowing rate based on Corvette at $22 \mathrm{~kg} / \mathrm{ha}$, with the other treatments at the same number of viable seeds per ha. Pitau white clover was also sown $2 \mathrm{~kg} / \mathrm{ha}$ The layout was a randomised block design with 5 replicates. The trial was grazed with dairy cattle according to the farmers forage requirements. The grazing rotation ranged from 18-21 days in spring to around 80 days in winter. In August, October, February and May strips were trimmed with a mower after grazing and regrowth measured at the same height $(3-4 \mathrm{~cm})$ before the next grazing. Botanical composition was determined on a dry matter basis on the yield measurement areas.

Helensville site Moata, Tama, and Corvette were compared with Ellett perennial ryegrass from April 1983 - November 1984, on a Kaipara clay near Helensville. The trial was drilled into lightly cultivated ground, at a seeding rate for the ryegrass of 20 $\mathrm{kg} / \mathrm{ha}$ plus Huia white clover at $2 \mathrm{~kg} / \mathrm{ha}$. Plots were $100 \mathrm{~m}^{2}$ and separated by buffer strips of Ellett to prevent contamination among the short-term ryegrasses. The experimental design was a randomised block with 4 replicates. This site was also grazed according to the farmer's forage requirements. In the first winter sheep were used, calves in the spring and dairy cattle for the remainder of the time. Yields of each plot were determined approximately monthly from July 1983 to November 1984, by measuring regrowth from 2 grazing exclosure frames on each plot. Handcut samples were bulked on a treatment basis for botanical composition analysis. Data were pooled into seasons on a whole-cut basis.

Edgecumbe site Pastures based on Moata, Paroa, Corvette, Ellett and Ellett plus Corvette sown as a mixture were compared from August 1983-November 1987. The trial was sown in April 1983 into cultivated ground of Awakeri sandy loam on shallow peat soil. Plots were $150 \mathrm{~m}^{2}$ and separated by a $3 \mathrm{~m}$ buffer of Ellett. There were 4 replicates with a randomised block layout. The Corvette, Paroa, Moata and Ellett treatments were all sown at $20 \mathrm{~kg} / \mathrm{ha}$ and the Corvette/Ellett mixture at $15 \mathrm{~kg} / \mathrm{ha}$ Corvette and $5 \mathrm{~kg} / \mathrm{ha}$ Ellett. This mixture was designed to prevent suppression of Corvette by the perennial ryegrass component. The trial was grazed by dairy cattle according to the farmer's requirements, with rotation lengths varying from 21 days 
in spring to around 100 days in winter. Yields were assessed with a pasture capacitance probe from untrimmed areas within grazing exclosure frames over the period from one grazing to the completion of the following grazing. Botanical composition of each plot was visually assessed at each grazing from within the frame, with the calibration of the visual assessment checked each 6 months. Data were pooled into the 4 seasons.

\section{RESULTS}

Yields under mowing (Table 1)

All trials established well. Over the 12 months afler sowing total yields ranged from 4-17 t DM/ha. Most were in the 8-10 $\mathrm{t} \mathrm{DM/ha} \mathrm{range} \mathrm{and} \mathrm{had} 80-100 \%$ ryegrass content. Data in Table 1 are the mean values of the 2 cutting intervals. Any cutting interval by cultivar interactions are described in the text.

Table 2: Comparisons of short-term negrasses sown as pure wards in 12 months after sowing (data are ryegrass component yields expressed relative to Moata $=100$ plus absolute yields $(\mathrm{kg} \mathrm{DM} / \mathrm{ha}$ ) of Moata; mean values of the 2 cutting intervals)

\begin{tabular}{|c|c|c|c|c|c|c|c|c|c|}
\hline \multirow{3}{*}{$\begin{array}{l}\text { Trial } \\
\text { A }\end{array}$} & \multirow{3}{*}{$\begin{array}{l}\text { Site } \\
\text { Rukuhia }\end{array}$} & \multirow{3}{*}{$\begin{array}{l}\text { Period } \\
\text { Win } 1983\end{array}$} & \multicolumn{3}{|c|}{ Short-term ryegrass } & \multirow[b]{2}{*}{ Corvette } & & \multirow[b]{2}{*}{ LSD } & \multirow[b]{2}{*}{$(5 \%)$} \\
\hline & & & \multirow{2}{*}{$\begin{array}{c}\text { Manawa } \\
101\end{array}$} & \multicolumn{2}{|c|}{ Moata } & & & & \\
\hline & & & & 100 & (3580) & 117 & & & 5 \\
\hline & & Spr 1983 & 91 & 100 & (7520) & 104 & & & 6 \\
\hline & & Sum $1983 / 84$ & 60 & 100 & (3240) & 90 & & & 15 \\
\hline & & Aut 1984 & 82 & 100 & (3170) & 117 & & & 11 \\
\hline & & Total & 86 & 100 & (17510) & 107 & & & 5 \\
\hline \multirow[t]{5}{*}{ a } & Rukuhia & Aut 1984 & 100 & 100 & (220) & 132 & & & 41 \\
\hline & & Win 1984 & 105 & 100 & $(2850)$ & 122 & & & 5 \\
\hline & & Spr 1984 & 92 & 100 & (5470) & 101 & & & 6 \\
\hline & & sum 1984/85 & 30 & 100 & $(570)$ & 25 & & & 25 \\
\hline & & Total & 93 & 100 & (9110) & 103 & & & 5 \\
\hline \multirow[t]{6}{*}{ C } & Rukuhia & Aut 1985 & 89 & 100 & ( 890$)$ & 138 & & & 16 \\
\hline & & Win 1985 & 98 & 100 & (2510) & 112 & & & 6 \\
\hline & & Spr 1985 & 91 & 100 & (5280) & 117 & & & 9 \\
\hline & & sum $1985 / 86$ & 32 & 100 & (930) & 84 & & & 43 \\
\hline & & Total & a7 & 100 & (9610) & 115 & & & 6 \\
\hline & & & Paroa & & Aoata & Tama & Corvette & SE & \\
\hline \multirow[t]{6}{*}{ D } & Edgecumbe & Win 1983 & 90 & 100 & $(790)$ & 134 & 76 & & 9 \\
\hline & & Spr 1983 & 96 & 100 & $(3200)$ & 85 & 124 & & 10 \\
\hline & & Sum $1983 / 84$ & 44 & 100 & ( 790$)$ & 45 & 252 & & $21^{i}$ \\
\hline & & Aut 1984 & 102 & 100 & ( 40) & 101 & 435 & & $12^{\prime}$ \\
\hline & & Total & a7 & 100 & (4830) & 87 & 140 & & $9^{\prime}$ \\
\hline & & & Paroa & & Aoata & Tama & Progrow & LSD & $(5 \%)$ \\
\hline \multirow[t]{4}{*}{$E$} & Rukuhia & Aut 1984 & 84 & 100 & $(1280)$ & 120 & 105 & & 20 \\
\hline & & Win 1984 & 102 & 100 & $(3090)$ & 106 & 96 & & 5 \\
\hline & & Spr 1964 & 112 & 100 & (3290) & 69 & 83 & & $9^{i}$ \\
\hline & & Total & 103 & 100 & (7660) & 92 & 92 & & 6 \\
\hline \multirow[t]{4}{*}{$F$} & Rukuhia & Aut 1985 & 87 & 100 & (1180) & 114 & 127 & & 14 \\
\hline & & Win 1985 & 97 & 100 & (2670) & 106 & 94 & & 4 \\
\hline & & Spr 1985 & 121 & 100 & $(4060)$ & 51 & a4 & & $10^{i}$ \\
\hline & & Total & 108 & 100 & (7910) & 78 & 94 & & $6^{i}$ \\
\hline \multirow[t]{4}{*}{ G } & Rukuhia & Aut 1986 & 71 & 100 & ( 590$)$ & 100 & 122 & & 17 \\
\hline & & Win 1986 & 100 & 100 & (3660) & 104 & 102 & & 5 \\
\hline & & Spr 1986 & 101 & 100 & $(5160)$ & 76 & a4 & & $6^{i}$ \\
\hline & & Total & 99 & 100 & (9410) & 66 & 93 & & 3 \\
\hline
\end{tabular}

$\mathrm{i}=$ significant cultivar by cutting frequency interaction

239. 
At sites A-C Manawa was inferior to Moata, though most of the difference occurred in summer and autumn. That is, Manawa yields were similar to those of Moata over winter and spring. Corvette was superior to Moata in each of the seasons except summer and had greater yields overall.

At Edgecumbe there were significant cultivar by cutting frequency interactions in all seasons, the main effect being that the differences between cultivars were much smaller at the 3-week than the 6-week interval. Paroa was inferior to Moata, particularly in summer. Tama started strongly, being much stronger than Moata in winter, but over 12 months its yields were lower than those of Moata. Corvette was inferior to Moata in winter but was substantially stronger in spring, summer and autumn, as well as giving a higher total yield over 12 months.

In trials E-G Paroa was inferior to Moata in the autumn of sowing but was equal or superior to Moata in winter and spring. Tama and Progrow both had very strong autumn growth. In winter Tama had a small but consistent margin over Moata Progrow tended to be slightly poorer over this period. In spring both Tama and Progrow were inferior to Moata and taken overall both had lower total yields than Moata (over the 3 seasons). There was an interaction where yield of Tama was significantly lower than the other cultivars at the 2-weekly cutting interval. This effect was not evident with the 4-weekly cutting.

\section{Yields in grazed pasture (Figs. 1 and 2)}

All ryegrass cultivars established well, being $90-100 \%$ of total yield in the winter after sowing. During establishment there were significant differences between the short-term cultivars but no consistent pattern between sites, with Moata performing well in the first winter at Edgecumbe and Corvette well at Katikati. All the short-term cultivars were superior to either Nui or Ellett in the first winter. None of the shortterm cultivars had consistently strong growth in summer or autumn.

At Katikati, the major pattern between Paroa, Manawa and Corvette was the higher yield of Corvette from the second year. This was generally reflected in higher total yields. At Helensville, the cultivars were ranked Corvette, Moata, and Tama but there were no significant effects on total yields. At Edgecumbe, Paroa was poor and no measurements were made after autumn of the second year. Corvette had substantially greater yields than Moata from year 2, which resulted in significantly higher total production each winter.

Both Nui and Ellett were usually significantly stronger than Corvette in summer and autumn but during winter and spring Corvette was at least as productive as Nui or Ellett. In a number of instances (winter 1982 at Katikati and winters 1984 and 1987 at Edgecumbe) the higher productivity of Corvette substantially increased winter yield over the perennial cultivar.

At both Bay of Plenty sites Corvette took 3-4 years to become a major sward component after a period of clover dominance. At Edgecumbe, plots sown with a mixture of Ellett and Corvette tended to behave like perennial ryegrass plots in summer and autumn and Corvette plots in winter and spring, clearly indicating that both ryegrasses were co-existing within the sward. Total yield of the Corvette/Ellett mixture was slightly higher than either component sown alone.

\section{DISCUSSION}

The trials highlighted strengths and weaknesses of the short-term ryegrasses. The Westerwold types, Tama and Progrow, had very rapid establishment, strong first winter growth but comparatively poor spring growth, and for Tama little persistence. Their role is clearly as catch crops between seasons.

Moata performed well in the first season relative to Tama or Progrow, but was 

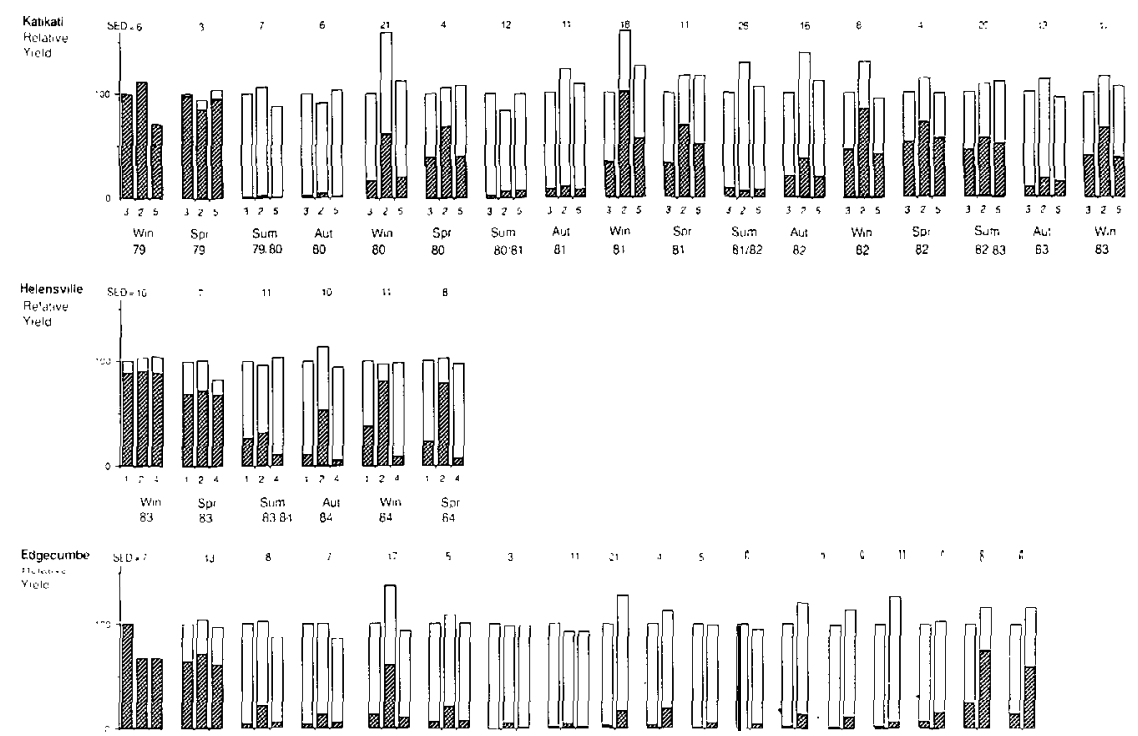

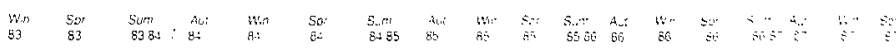

Figure 1: Comparisons of short term ryegrasses in grazed pastures. For each site yields are relative to Moata or Paroa Shaded areas are ryegrass component yields relative to total yield of Moata or Paroa

( 1 = Moata, 2 = Corvette. 3 = Paroa, 4 = Tama, 5 = Manawa)

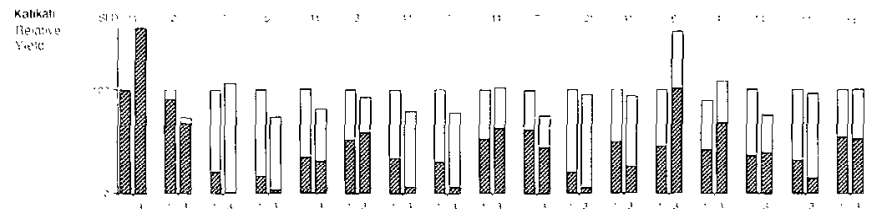

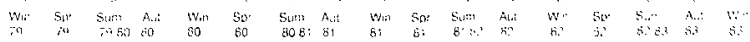

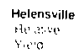

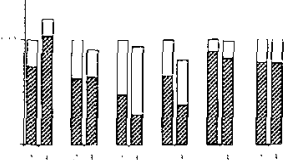

s.t.

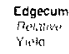

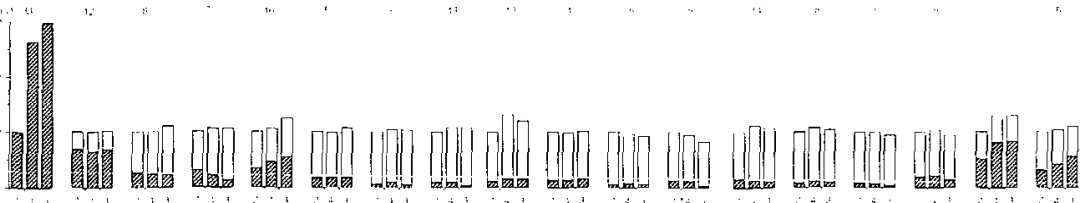

Figure 2: Comparisons of Corvette and perennial ryegrass in grazed pastures. For each site data are yields relative to total yield of Nui or Ellett.

( $1=$ Nui, $2=$ Eillett $3=$ Corvette. $4=$ Corvette/Ellett mixture) 
generally lower yielding and lacked the ability to persist of Corvette. These data contrast with those from spaced-plant evaluations at Palmerston North (Forde et al. 1988). Moata performed better than Paroa in the Edgecumbe cutting trial but there was no conclusive pattern from Rukuhia or the Edgecumbe grazing trial.

Manawa performed little differently from Paroa, which was contrary to the expectation from previous experiments (Harris \& Brougham 1970) that Manawa would have persistence similar to that of Corvette. The Katikati experiment was not subject to any unusual climatic events to explain the lack of persistence of Manawa

A potentially important factor in explaining differences in persistence between short-term ryegrasses is the incidence of an Acremonium-like endophytic fungus. Latch ef al. (1988) found its incidence in seed was Paroa zero, Manawa 34\%, Progrow $\mathbf{7 0 \%}$, Concord $75 \%$ and Corvette $\mathbf{8 8 \%}$, and speculated that its presence may protect seedlings from attack by Argentine stem weevil. Neither the endophyte status nor Argentine stem weevil populations were measured in the trials reported in this paper.

The most important finding from these experiments was the ability of Corvette to persist when sown alone or with perennial ryegrass. There was some evidence from the Edgecumbe trial that an Ellett/Corvette mixture was superior in both seasonal and total yields. Similar findings have been obtained from another experiment in the Waikato using an Ellett/Concord mixture (G.J. Goold, unpubl. data).

These findings bring into question the advice that has been offered to farmers throughout the Auckland province for at least the past 15 years, that they sow pastures based on perennial ryegrass alone. This may have been appropriate when persistence of the available short-term ryegrasses was such that they would perform only in the 12 months after the pasture was sown. The availability of regional ecotypes such as Corvette and Concord offers farmers potential benefits in the distribution of annual growth.

\section{Acknowledgements}

The authors gratefully acknowledge Mr G.A Wilks and Mr G.K. Evans for provision of trial sites on their farms, Mr M. Bennenbroek and Mr A Farrell for technical assistance in running the experiments, Miss B. Dow and $\mathrm{Mr} \mathrm{J}$. Waller for statistical analyses.

\section{References}

Forde, M.B.; Burgess, R.E. Halligan, E.A.; Gardiner, S.E; latch, G.C.M. 1988. Varieties of Italian ryegrass in New Zealand. Proceedings NZ Grassland Association 49: 101-106.

Harris, W.; Brougham R.W. 1970. The effect of grazing on the persistence of genotypes in a ryegrass population.

NZ journal of agricultural research 13: 263-76.

Latch, G.C.M.; Christensen, M.J.; Hickson, R.E. 1988. Endophytes of annual and hybrid ryegrasses. NZ journal of agricultural research 31: 57-63. 